\title{
The Impact of the Dividend Method on the China Listed Company's Stock Price
}

\author{
Zehui Peng \\ Henan University of Economics and Laws, Zhengzhou 450000, China \\ Email:pzhzyx199898@163.com
}

\begin{abstract}
This paper applies to the knowledge related to stock dividends, investment strategies, and basic stock market analysis. It mainly studies the impact of stock dividends on stock prices in the Chinese financial market environment. The article cites the findings of the empirical analysis of cash dividends of Chinese listed companies (2003) written by Liu Shulian and $\mathrm{Hu}$ Yanhong on the formulation of cash dividend strategies of listed companies. The article also relies on the empirical analysis of cash dividends of Chinese listed companies (2000) by Qin Jiangping and Wang Huaidong and the analysis of dividend policy of Chinese listed companies (2001) by Yuan Hongqi as the infrastructure for the analysis. It is concluded that stock dividends are beneficial to stock price appreciation and firm growth in the long run. In this process, the stock market can be gradually strengthened by the profitability of listed companies, and investors can benefit from stable dividends from listed companies, thus reducing speculative behavior.
\end{abstract}

Keywords: Dividends, stock, bonus shares, shareholder, China listed companies

\section{INTRODUCTION}

The dividend policy of a listed company, as one of the three major financial decisions of a company, has always been the focus of attention from the financial community. 1956 Harvard University Professor John Lintner first proposed the theoretical model of dividend distribution, and in 1961 Miller \& Modig Liani proposed the dividend is not related to enterprise value theory, which constitutes the theoretical cornerstone of dividend policy. In the following decades, academics have continued to challenge the MM theory, proposing various other possible explanations around the dividend distribution issue, but have been unable to reach a consensus. So much so that Fisher-Blake (1976) called it "Dividend Puzzle". In fact, dividend policy is a trade-off between reinvesting profits and rewarding investors, which has a bearing on the entitlements of shareholders and the long-term development of the company.

However, in China, many listed companies are not accustomed to making dividends one of the most important indicators of their business performance each year, due to the inadequacy of the securities market system or the short-sightedness of some company executives. They are so stingy with cash dividends that many equity investors are choosing their investments based on short-term stock price fluctuations rather than corporate dividends. This clearly creates a large number of speculators and impedes the development of the stock market.

Through the analysis and research of several dividend payment methods in the Chinese market, three representative dividend cases of listed companies are selected to reflect the impact of stock dividends on stock price volatility. In this process, in order to exclude the impact of sudden increase in a stock's share price by speculators and market travelers for speculative or speculative purposes, which is common in China, the time axis is used to analyze the impact of dividends on the share price. Therefore, the analysis chooses to lengthen the timeline and mainly analyze the stock movements under the influence of long-term stable dividends of listed companies, while ignoring short-term speculative fluctuations. The main expectation is that through the analysis of stock dividends on the impact of stock prices, to reduce speculative investment in the market, so that stock investors turn to focus on the dividend situation of listed companies to achieve the ideal investment purposes, to guide the dividend strategy of listed companies to positive and healthy development. 


\subsection{Purpose of Stock Dividends}

In fact, it is up to listed companies to decide whether to pay dividends or not, and there is no regulation in China that requires listed companies to pay dividends. In November 2019, the CSRC published a letter in response to the recommendations of the Second Session of the Thirteenth National Committee of the CPPCC No. 1842 [1]Finance, Tax and Finance No. 158, stating that cash dividends are an autonomous act of listed companies, and it is inappropriate to make mandatory provisions at the level of administrative regulations, rules and regulations. Although there are no mandatory provisions, there are still more listed companies that actually pay dividends, and those with sufficient profits also maintain their dividends.

Why do many public companies pay dividends to their shareholders when there is no mandatory requirement for profitable public companies to pay dividends? Mainly, shareholders are making investments because they are optimistic about the profitability of a particular company and believe that it has the potential to grow, which is why they will take their money out of their pockets and give it to a public company. If the company is able to pay a steady dividend, then it at least shows that the company's profitability and cash flow are very healthy, which is what shareholders are happy to see. Correspondingly, for listed companies, paying dividends helps attract investors' attention. Since most investors want to get dividends in the process of investment, they will pay great attention to the company's dividend payment in the past period when choosing investment objects. On the one hand, they want to know how fast the company is growing, and on the other hand, they want to know if the company is worth investing in. A stable dividend can attract a large amount of capital, and the company will have more capital to grow and develop.

\subsection{Dividends Paid by Listed Companies}

\subsubsection{The three main types of dividend payments in the world}

\subsubsection{Cash dividends}

A listed company distributes cash directly to its shareholders, who do not have to pay redemption fees and are tax-free. The company's accounting department will collate and calculate the revenue for the year and then estimate the investments and expenses required for the company's future growth. The company's operating profits for the year and previous undistributed profits are then distributed directly to shareholders as dividends in the form of cash. Cash dividends in several kinds of dividends is the most simplest one, but cash dividends will inevitably involve the problem of cash flow. That is, a listed company must balance the ratio of dividends and future investments at the time of profit distribution. This is because there is some contradiction between the shareholders' expectations of the listed company's stage earnings and the company's long-term future goals. If the listed company spends most of its revenue on dividends to shareholders, then the company will be financially constrained when it comes to expansion. However, if the company plans to spend the majority of its revenue on expanding the company, it may lead to a decline in shareholder confidence and loss of capital, which in turn may affect the stock price.

\subsubsection{Stock dividends}

Stock dividends are the payment of dividends by a company in the form of shares issued as dividends. Stock dividends do not directly increase the wealth of shareholders, do not lead to an outflow of company assets or an increase in liabilities, so they are not a use of company funds and do not increase the company's assets as a result, but they cause a change in the structure of the items of equity. In the financial indicators, the shares of stock given to the company are formed by the transfer of capital to the shareholders from the profits of the company's operations and productions or from the surplus accumulated in previous years. Shareholders will receive a proportional share of bonus shares (dividends paid in the form of shares) based on the number of shares they own. However, there is no change in the overall shareholding structure because the bonus shares are paid out in proportion to the shareholder's ownership. In fact, this corresponds to no change in the proportion of shares held by each shareholder, only an increase in the number of shares.

\subsubsection{Dividends in kind}

Some companies pay dividends in kind to their shareholders. For example, a product produced or a security held by the company. Paying dividends in kind is actually very beneficial to some listed companies, as the products produced will be paid out as dividends, which on the one hand can reduce the company's inventory and increase sales; on the other hand, when dividends are paid out in kind, the company's cash flow will be protected, so the impact of this type of dividends on listed companies is minimal. Of course, if all the shareholders start using the company's products, this is like giving this company free advertising, which is very helpful for the company to expand its influence. However, such advertisements are often accompanied by negative effects as well. For example, in the study of the stock price correlation between in-kind dividends and cash dividends [2], starting from the event of Southern Food's payment of in-kind dividends to its shareholders on April 3, 2013, using the event research method, 16 samples of 10 listed companies that paid 
in-kind dividends from 2007 to 2013 were selected for analysis and research, and it was concluded that in-kind dividends will cause a decline in stock price and a decrease in cumulative excess earnings, because While the payment of in-kind dividends attracts investor attention, investors mostly view them as a marketing tool, a way to dispose of inventory, or a gimmick that has a negative impact on the stock price.

\subsubsection{Major dividend payment methods in China}

In fact, dividends in Chinese listed companies are still mainly in the form of cash dividends and bonus shares. In the late 20th century and early 21 st century, dividends in kind were also common, but with the gradual development of the capital market, the form of dividends in kind gradually disappeared. Cash dividends, on the other hand, are a more common form of dividends than stock dividends.

\subsection{The Impact of Dividend Payments on Share Prices of Listed Companies' Shares}

\subsubsection{Stock dividends}

When dividends are paid in the form of stock dividends, the company usually transfers the amount of dividends to which the shareholders are entitled to capital, issues new stock in an amount equal to that amount, and distributes it in proportion to the shareholders' ownership. While this approach does not change the capital structure, it will reduce earnings per share and the market price of the stock. This gives other investors the opportunity to enter the market, as the relatively low stock price is conducive to stock trading and circulation. Also, by using bonus shares as a dividend, there is no cash outflow for the company and it does not lead to a reduction in the company's assets.

On the face of it, this does not produce a material gain for either the shareholders or the company, but the fact is that the various shareholders own more stock, and once the stock goes up, their assets will rise at an accelerated rate. For example, shareholder A of publicly traded company A owns five percent of the stock of company A. The price per share is $\$ 100$ and the number of shares is 10,000 . Then it can be deduced that the total number of shares of stock in Company A is 200,000 shares. When Company A takes stock dividends and pays dividends at a ratio of 10 -for- 2 , then after the dividend, the number of shares in Company A increases to 240,000 , and the number of shares in the hands of shareholder A is 12,000 at a price of $\$ 83.33$ per share. At this time, the changes are in Company A's total capital stock, net asset value per share, and earnings per share, and there is no change in the return related to assets. That is, the assets owned by shareholder A have not increased at this time, but if the price of Company A's stock rises by one dollar to $\$ 84.33$ per share, then the assets owned by shareholder A have changed from $\$ 1,000,000$ to $\$ 1,012,000$ (84.33 x 12000). However, if no bonus shares are distributed, then when the stock price of Company A rises by $\$ 1$ and becomes $\$ 101$ per share, then the assets owned by shareholder A rises from $\$ 1,000,000$ to $\$ 1,012,000(101 \times 10,000)$, which is $\$ 2,000$ less than in the bonus share distribution case. Therefore, it is possible for the shareholder to get more return on his investment by paying a stock dividend than a cash dividend.

After the dividend occurs, (following the example above) Company A's share price becomes $\$ 83.33$ per share, at which point $\$ 83.33$ per share is more attractive to investors who are watching, as opposed to $\$ 100$ per share. And by making a dividend, Company A is itself sending a signal to the market, which increases the confidence of investors who are watching. Because the market and investors generally believe that a company that pays a stock dividend tends to indicate greater development and growth, such messaging will not only stabilize the stock price but may even cause it to rise. I'd like to share with readers a stock, Hengrui Pharma (600276), that has maintained a percentage of its stock dividend almost every year. Moreover, this company's stock price is still going up, and it is gradually growing into a recognized quality stock, which many Chinese funds allocate to their portfolios. It must be said that its stable stock dividend has gradually brought it to the attention of many investors, but also because it is doing well enough to support such a fixed dividend policy. In a way good stocks and investors are mutually fulfilling.

Table 1 Hengrui Pharma (600276) Stock Dividend, 2010-2020

\begin{tabular}{|l|c|c|c|}
\hline $\begin{array}{l}\text { Bulletin } \\
\text { Date }\end{array}$ & $\begin{array}{l}\text { Dividend cut-off } \\
\text { date }\end{array}$ & $\begin{array}{l}\text { Basis of dividend-paying share } \\
\text { capital }\end{array}$ & $\begin{array}{l}\text { Bonus shares for every 10 } \\
\text { shares }\end{array}$ \\
\hline $2010-03-10$ & $2009-12-31$ & 620743220 shares & 3.0000 shares \\
\hline $2011-04-19$ & $2010-12-31$ & 749433164 shares & 1.0000 shares \\
\hline $2012-05-22$ & $2011-12-31$ & 112414974 shares \\
\hline $2013-06-03$ & $2012-12-31$ & 1236564721 shares & 1.0000 shares \\
\hline $2014-05-09$ & $2013-12-31$ & 1360221193 shares & 1.0000 shares \\
\hline
\end{tabular}




\begin{tabular}{|c|c|c|c|}
\hline $2015-05-30$ & $2014-12-31$ & 1504999312 shares & 2.0000 yuan \\
\hline $2016-06-08$ & $2015-12-31$ & 1956469076 shares & 2.0000 shares \\
\hline $2017-05-22$ & $2016-12-31$ & 2347459674 shares & 2.0000 shares \\
\hline $2018-05-24$ & $2017-12-31$ & 2832648038 shares & 2.0000 shares \\
\hline $2019-03-21$ & $2018-12-31$ & 3685862057 shares & 2.0000 shares \\
\hline $2020-05-19$ & $2019-12-31$ & 4422291951 shares & \\
\hline
\end{tabular}

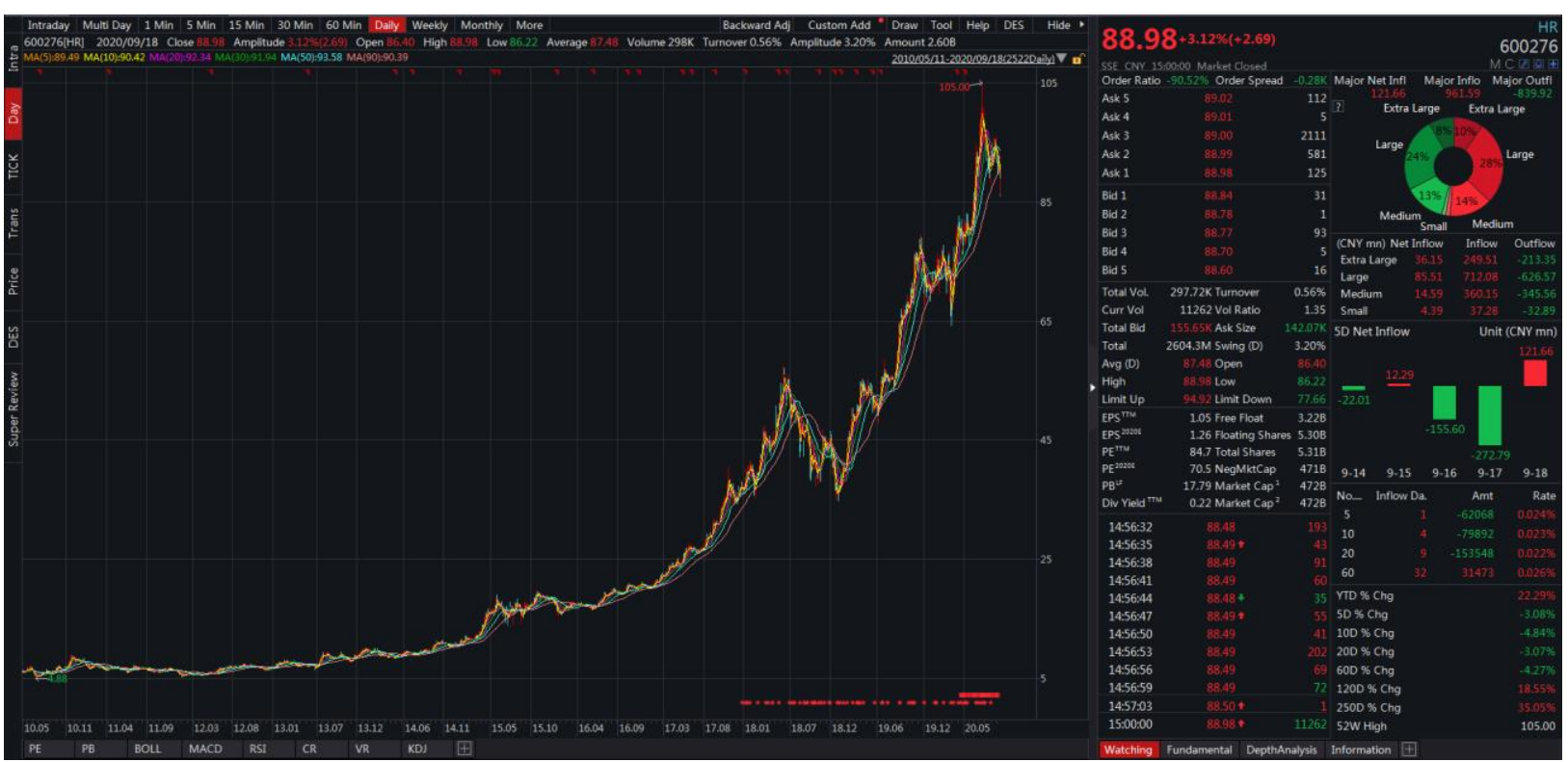

Figure 1 Pientzehuang Stock Price Trend Data from Wind (2010.5-2020.5)

Therefore, dividends in the form of stock dividends on the stock price will have an obvious role in promoting the rise, but at the same time, also need to pay attention to one point, that is, too much stock dividends, will increase the total amount of shares, affect the company's future level of dividends per share and the market price of the stock, is not conducive to the company's market image to improve and increase working capital.

\subsubsection{Cash dividends}

From an investor's point of view, the reason for investing in stocks is the expectation of a good cash payout. And for most shareholders, it is more prudent to "pocket the cash." But for the company, cash dividends mean that the company's cash flow will take a hit, especially for growth-oriented public companies. While growth-oriented public companies may earn higher profits each year, these types of companies are in a phase of rapid expansion, and they need large amounts of capital to expand production. If a large percentage of cash dividends are paid at this time, the company's cash flow may be affected and may even lead to a cash flow break, which is a very scary thing to do. This is why many growth-oriented public companies choose to reduce their dividends or pay little or no dividends to protect their cash flow in order to support their expansion needs.

In China's A-share market, cash dividends of listed companies are positively correlated with earnings per share and asset size in the decision period, and negatively correlated with gearing.[3] And listed companies that pay a stable and high percentage of cash dividends tend to be state-owned enterprises, as they do not face obstacles to expansion, and even with the support of the state, they do not experience a break in the capital chain. In any case, cash dividends are generally good for increasing shareholder wealth. Since most of the stock market participants are not financially literate, their investment strategy is often to "follow". For example, at a certain point in time, a higher proportion of the dividend of listed companies will become the object of attention, many people will be full of confidence in high dividend companies, because investors will often have a psychological expectation in the heart of a stock, this expectation is derived from their concern for the stock, they believe that high dividend companies are undoubtedly an excellent 
enterprise, but also worthy of investment objects. On the other hand, the complete mismatch between the share price and the company' $\mathrm{s}$ business situation in the A-share market happens from time to time, leading most shareholders to believe that cash dividends are a more secure way to pay dividends as opposed to stock dividends. Shareholders are more inclined to invest in listed companies that pay cash dividends, which will undoubtedly push up the share price of these companies.
To share an example with you, Pientzehuang (600436), an enterprise listed on China A-shares, has been paying cash dividends every year since it went public in 2003. (Only the dividends from 2010 to the present are shown here) Even with the impact of the epidemic in 2020 , Pientzehuang will still be able to pay cash dividends. With such steady dividends, few investors would doubt its business performance, and its stock price has rightfully gone all the way up.

Table 2 Pientzehuang ( 600436 ) Cash dividends, 2010-2020

\begin{tabular}{|c|c|c|c|}
\hline Bulletin Date & Dividend cut-off date & $\begin{array}{c}\text { Basis of dividend-paying share } \\
\text { capital }\end{array}$ & $\begin{array}{c}\text { Per 10 shares in cash } \\
\text { (including tax) }\end{array}$ \\
\hline $2010-06-11$ & $2009-12-31$ & 140000000 shares & $5.0000 y u a n$ \\
\hline $2011-06-17$ & $2010-12-31$ & 140000000 shares & $7.0000 y u a n$ \\
\hline $2012-05-25$ & $2011-12-31$ & 140000000 shares & 8.0000 yuan \\
\hline $2013-05-28$ & $2012-12-31$ & 140000000 shares & $11.0000 y u a n$ \\
\hline $2014-06-20$ & $2013-12-31$ & 160884589 shares & $9.0000 y u a n$ \\
\hline $2015-05-30$ & $2014-12-31$ & 160884589 shares & $3.5000 y u a n$ \\
\hline $2016-05-18$ & $2015-12-31$ & 402211473 shares & $2.7000 y u a n$ \\
\hline $2017-06-06$ & $2016-12-31$ & 603317210 shares & $4.3000 y u a n$ \\
\hline $2018-06-01$ & $2017-12-31$ & 603317210 shares & $6.0000 y u a n$ \\
\hline $2019-06-20$ & $2018-12-31$ & 603317210 shares & $8.2000 y u a n$ \\
\hline $2020-06-17$ & $2019-12-31$ & 603317210 shares & \\
\hline & & & \\
\hline
\end{tabular}

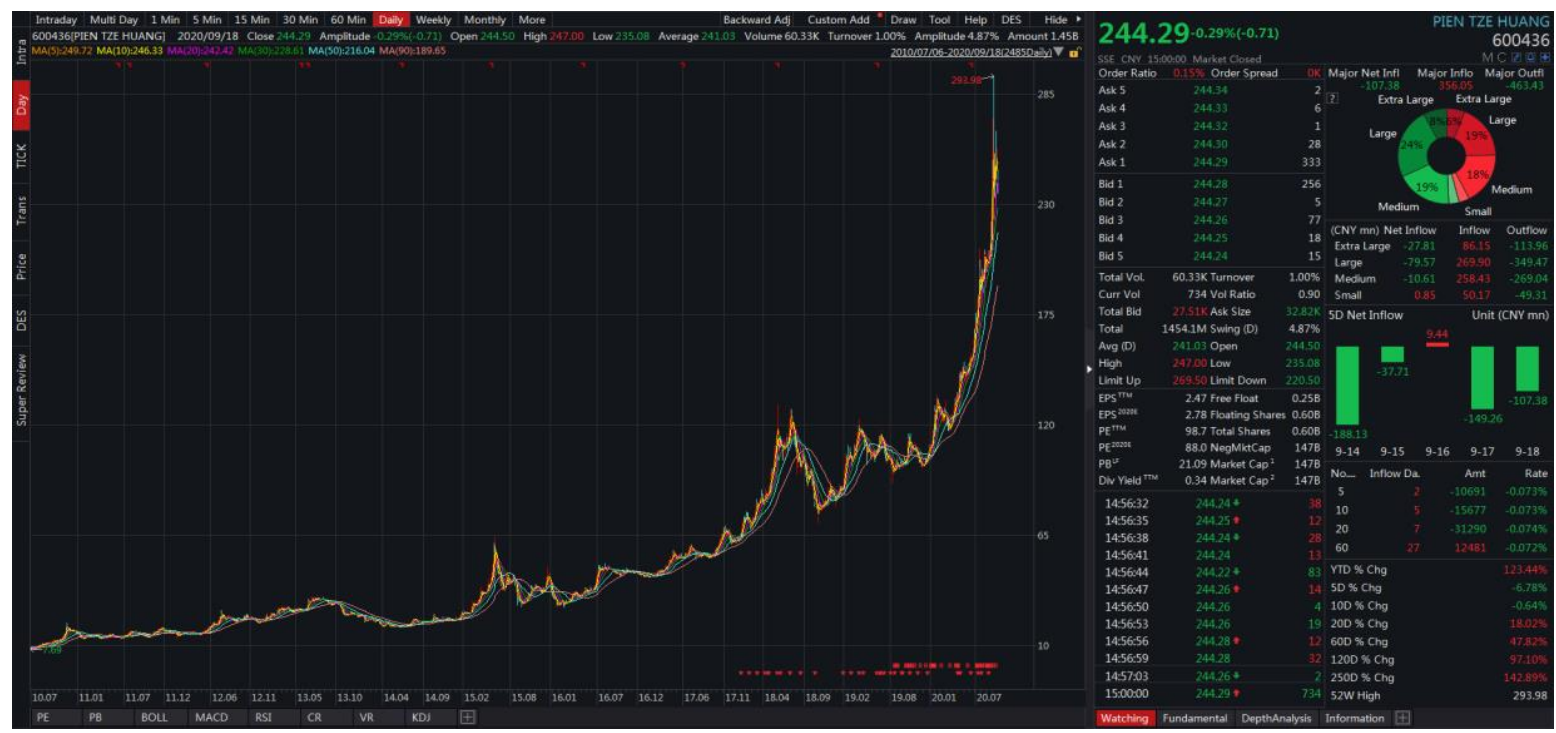

Figure 2. Hengrui Pharmaceutical's Share Price Trend Data from Wind 1 ( 2010.7-2020.7 ) 


\section{CONCLUSION}

Overall, from the short-term operating conditions of listed companies, cash dividends will indeed have a certain impact on the company's cash flow, in the short term on the operating health of listed companies, resulting in lower share prices; however, in the long term, stable cash dividends illustrate the company's good operating conditions and business policy is relatively coherent, investors will undoubtedly be more optimistic about such stocks, increasing the number of holdings and then Pushing up stock prices. In-kind dividends in general are gimmickier and speculative, and do not significantly help the long-term development and stock growth of listed companies, and may have some negative effects. This type of dividend is currently rarely used by Chinese listed companies. Stock dividends will dilute the shareholding in the short term, and in essence, shareholders do not get any real benefit from the stock dividends. And this kind of dividends can even cause the share price to fall for a short period of time. But from an investor's point of view, prices below market expectations are a good time for them to enter the holding because the market's expectation of a low level is often that the stock price is about to move higher, so much so that many investors will see this signal to increase their holdings and thus push the price higher.

Of course, the examples cited in the article mainly analyze the role of cash dividends and stock dividends in driving up the share price. However, it is undeniable that some listed companies will cooperate with the media to speculate on their dividend strategy in order to drive up the share price, and these "grey areas" are not mentioned in the article. In future research on stock dividends, we should fully consider the synergistic effects of other industry interventions in order to make the analysis in this area more complete and the theory more convincing.

\section{ACKNOWLEDGMENT}

In the process of writing my thesis, many people have provided me with valuable help, including my supervisor, my classmates and my parents.First of all, I would like to express my sincere thanks to my supervisor, Professor Sun, who helped me with extraordinary patience and consistent encouragement by providing me with necessary information, valuable advice and inspiration for new ideas. It was her advice that brought to my attention some of the shortcomings and brought clarity to many things. This dissertation could not have taken its present form without her strong support.Secondly, a heartfelt thank you to Eva Chen, the teacher of my dissertation writing course, for her help in the process of writing my dissertation and for her inspiring lectures that benefited me so much.Then, I am pleased to thank my classmates for their invaluable help throughout the preparation of the original manuscript, and for their extensive comments and sound advice on the outline of this paper. I would like to give special thanks to my friend, Mengjie Lee, for her help in writing my thesis. She has always been able to give me very pertinent advice from a professional point of view, and the data in the original manuscript was able to be sorted out thanks to her help. Finally, I would like to give special thanks to my parents for their support by providing me with the computer to search for information, which helped me to successfully complete this thesis, and I would like to express my gratitude to all those who helped me in the writing process.

\section{REFERENCES}

[1] CSRC(2019)Letter on the Response to the Proposal No. 1842 (Taxation and Finance 158) of the Second Session of the Thirteenth National Committee of the CPPCC, http://www.csrc.gov.cn/pub/zjhpublic/G00306201/ 201911/t20191129 366696.htm?keywords=

[2] J. Wang,(2013) Research on stock price correlation between dividends in kind and cash dividends [D]. Yangzhou University.

[3] S. Liu, Hu Hongyan,(2003)An Empirical Analysis on Cash Dividend Payment of Listed Company in China. Accounting Research, 2003(4):29-35.

[4] H. Yuan, (2001) Dividend policy analysis of listed companies in China[J]. Financial and Economic Research, 2001(03):34-42.

[5] T. Ao, (2004) Dividend policy analysis of listed companies in China[J]. The Economist, 2004(06):102-103.

[6] J. Qin, Wang Huaidong, (2004) An Empirical Analysis of Cash Dividends of Listed Companies in China[J]. Financial Accounting Research, 2004(8):45-48.

[7] 2014. The impact of the way public companies pay dividends on stock prices. https://wenku.baidu.com/view/e5be772a7e21af45b 207a83e.html. 